\title{
HUBUNGAN KESULITAN BELAJAR MATEMATIKA TERHADAP KEMAMPUAN KONEKSI MATEMATIKA PADA SISWA SMK KARTIKA 1 SURABAYA
}

\author{
Elok Hidhayati Hartanti \\ (SMK Kartika 1 Surabaya) \\ elokhidhayati@gmail.com
}

\begin{abstract}
This research is motivated by the low ability students' mathematical connections. Mathematical reasoning and connections are two basic mathematical ability that must be mastered middle school students. However, many students have problems and learning difficulties in solving mathematical problems. Through the process of mathematical connections, conceptual thinking and students' horizons will be broader, the students will have the skills to solve problems and make decisions. The problem of this research is "Is there any connection to the students' mathematics learning difficulties mathematical connection capability? ". Subjects in these criteria is a class XI student of SMK Kartika Accounting 1 Surabaya. Data obtained by questionnaire to measure students' learning difficulties and then given treatment for the provision of learning achievement test items to get valid data. Based on the analysis of data by using the formula Pearson product moment is known H_0 is no relationship difficulty learning mathematics against the ability to connect mathematics to the students of class XI AK-1 SMK Kartika 1 Surabaya while the H1 is no relationship difficulty learning mathematics against the ability to connect mathematics to the students of class XI AK-1 SMK Kartika 1 Surabaya. Of the formula product moment correlation can be obtained rhitung with significance level of 5\% showed greater than the value rtabel $=0.344$ and rhitung $=0.45$; where $r$ hitung $>$ r_tabel or $0.45>0.344$, it can be concluded that learning difficulties affect the ability of students' mathematical connections.
\end{abstract}

Keywords: Learning Difficulties, Mathematics Connection Capability

\section{PENDAHULUAN}

Pendidikan sebenarnya merupakan suatu rangkaian peristiwa yang kompleks.Peristiwa tersebut merupakan rangkaian kegiatan komunikasi antar manusia sehingga manusia itu bertumbuh sebagai pribadi yang utuh.Manusia bertumbuh melalui belajar, tidak dapat melepaskan diri dari mengajar. Mengajar dan belajar merupakan proses kegiatan yang tidak dapat dipisahkan. Proses kegiatan tersebut sangat dipengaruhi oleh faktor yang sangat menentukan keberhasilan belajar peserta didik.

Menurut Kline (dalam Mulyono, 2010:252), matematika merupakan bahasa simbolik dan ciri utamanya adalah penggunaan cara bernalar, deduktif, tetapi juga tidak melupakan cara bernalar induktif. Dari paparan tersebut tidak semua anak mudah mempelajari matematika.Menurut Johnson dan Myklebust (dalam Andriyani, 2014: 9), matematika adalah bahasa simbolik yang fungsi praktisnya untuk mengekspresikan hubungan - hubungan kuantitatif dan keruangan sedangkan fungsi teoritisnya adalah untuk memudahkan berfikir. Dilihat dari kenyataan yang ada banyak siswa yang mengungkapkan susah untuk menyelesaikan masalah matematika.

Belajar merupakan kegiatan penting setiap orang, termasuk didalamnya belajar bagaimana seharusnya belajar. Sebuah survey memperlihatkan bahwa $82 \%$ anak - anak yang masuk sekolah pada usia 5 atau 6 tahun memiliki citra diri yang positif tentang kemampuan belajar mereka sendiri. Tetapi angka tinggi tersebut menurun drastis menjadi hanya $18 \%$ waktu mereka berusia 16 tahun.Konsekuensinya, 4 dari 5 remaja dan orang dewasa memulai pengalaman belajarnya yang baru dengan perasaan ketidaknyamanan (Nichol, 2002: 37).

Menurut Lerner (dalam Ehan 1981: 35), ada beberapa karakteristik anakberkesulitan belajar matematika, yaitu: adanya gangguan dalam hubungan keruangan, abnormalitas persepsi visual, asosiasi visual motor, perseverasi, kesulitan mengenali dan memahami simbol, 
Elok Hidhayati Hartanti : Hubungan Belajar Matematika Terhadap Kemampuan Koneksi Matematika Pada Siswa SMK Kartika 1 Surabaya

gangguan penghayatan tubuh, kesulitan dalam bahasa dan membaca, Scor Performance IQ jauh lebih rendah dari pada skor verbal IQ.

Menurut Lerner (dalam Ehan 1988: 430), kurikulum bidang matematika hendaknya mencakup tiga elemen, yaitu: konsep, keterampilan, dan memecahkan masalah. Dalam kurikulum 2004, penalaran dan koneksi matematis merupakan dua kemampuan dasar matematis yang harus dikuasai siswa sekolah menengah.Namun hasil belajar matematika siswa selama ini masih belum menggembirakan khususnya dalam aspek penalaran dan aspek koneksi matematika.

Dalam proses pembelajaran siswa bertanggung jawab terhadap hasil belajarnya sendiri. Hasil belajar yang belum menggembirakan diatas antara lain karena model pembelajaran matematika kurang mendorong siswa berinteraksi dengan sesama siswa dalam belajar, dan kurang mendorong siswa menggunakan penalaran. Siswa belajar secara individual, terisolasi, bekerja sendiri dalam memahami dan menyelesaikan masalah matematika, dan siswa kurang menggunakan nalar yang logis dalam menyelesaikan masalah matematika.

Melalui proses koneksi matematis, konsep pemikiran dan wawasan siswa akan semakin lebih luas, maka siswa akan memiliki kecakapan dalam memecahkan masalah dan mengambil keputusan secara masuk akal (reasonable), mendalam (in dept), dapat di pertnggungjawabkan (responsible) dan berdasarkan pemikiran yang cerdas (skillfull thinking).

Dari uraian di atas, penelitian ini ingin menjawab permasalahan, adakah hubungan kesulitan belajar matematika terhadap kemampuan koneksi matematika pada siswa SMK Kartika 1 Surabaya?yang hasilnya diharapkan dapat bermanfaat khususnya bagi guru matematika sebagai referensi dalam upaya mengembangkan pembelajaran matematika di sekolah. Dengan demikian, penelitian ini bertujuan untuk mengetahui hubungan kesulitan belajar matematika siswa terhadap kemampuan koneksi matematika siswa.

\section{METODE PENELITIAN}

Jenis penelitian ini adalah penelitian kuantitatif. Rancangan penelitian kali ini, menggunakan pendekatan eksperimen dengan jenis Pre-Eksperimental Design.Jenis desain dalam kategori Pre-Eksperimental Design yang digunakan adalah One-Shot Case Study. Desain ini hanya mengadakan treatment satu kali yang diperkirakan sudah mempunyai pengaruh. Pengaruh tersebut diketahui dari hasil post-test

Metode pengumpulan data pada penelitian ini menggunakan metode angket dan metode tes.Penelitian ini dilaksanakan di SMK Kartika 1 Surabaya, dengan populasi seluruh siswa kelas XI SMK Kartika 1 Surabaya. Pengambilan sampel pada penelitian ini menggunakan metode simple random sampling yakni cara penganbilan sampel secara acak dan di dalam pengambilan sampelnya, peneliti "mencampur" subjek-subjek di dalam populasi sehingga semua subjek dianggap sama.

Data yang diperoleh dari hasil penelitian ini untuk selanjutnya dianalisis.Hasil analisis data pada penelitian ini digunakan untuk pengujian hipotesis. Adapun langkahlangkah menghitung koefisien korelasi antara kedua variabel adalah sebegai berikut:

1. Menghitung jumlah kasus $(N)$

2. Menghitung dari jumlah skor dari masing - masing variabel $\sum X Y$ dan variable tergantung $\sum X$

3. Menghitung jumlah kuadrat dari masing-masing variable bebas $\sum(X)^{2}$ dan variable tergantung $\left(\sum X\right)^{2}$

4. Menghitung jumlah koefisien korelasi antara variable bebas $(X)$ dengan variable tergantung $(Y)$

Setelah dilakukannya perhitungan koefisien korelasi, selanjutnya pengujian hipotesis.Dari pengujian hipotesis dapat ditarik kesimpulan. Adapun langkah-langkah pengujian hipotesis sebagai berikut:

1. $H_{0}: \neq 0$. (Tidak ada hubungan kesulitan belajar matematika terhadap kemampuan koneksimatematikapada siswa kelas XI AK-1 SMK Kartika 1 Surabaya) . 
$H_{1}: \neq 0$. (Ada hubungan kesulitan belajar matematika terhadap kemampuan koneksi matematika padasiswa kelas XI AK-1 SMK Kartika 1 Surabaya).

2. Menentukan tingkat kepercayaan /signifikan: $\alpha=5 \%$

3. Menentukan kriteria pengujian, yaitu menentukan daerah penerimaan $H_{0}$.

4. Perhitungan nilai " $r$ "

5. Penarikan kesimpulan

\section{HASIL DAN PEMBAHASAN}

Setelah melakukan penelitian, dikatakan pada penggunaan rumus tabel korelasi Product Moment bahwa setelah diperoleh nilai $r$, lalu dikonsultasikan ke Tabel $r$ Product Moment demikian pula dalam penggunaan rumus ini.Terdapat cara lain yang sederhana dan mudah yaitu menggunakan intepretasi terhadap koefisien korelasi yang diperoleh atau nilai $r$. Intepretasi tersebut adalah sebagai berikut.

Tabel 1 Tabel Intepretasi

(Sumber: Prosedur Penelitian Suatu Pendekatan Praktik,

\begin{tabular}{|llll|}
\hline \multicolumn{3}{|c|}{ Besarnya Nilai $r$} & Intepretasi \\
\hline Antara & 0,800 & sampai dengan & Tinggi \\
1,00 & & & Cukup \\
Antara & 0,600 & sampai dengan & Agak Rendah \\
0,800 & & & \\
Antara & 0,400 & sampai dengan & Sangat Rendah \\
0,600 & & & \\
Antara & 0,200 & sampai dengan 0, & \\
400 & & & \\
Antara & 0,000 & sampai dengan & \\
0,200 & & & \\
\hline
\end{tabular}

Dari hasil analisis data di atas, dapat disimpulkan bahwa ada hubungankesulitan belajar matematika terhadapkemampuan koneksi matematika pada siswa kelas XI AK-1 SMK Kartika 1 Surabaya, hal ini dapat dilihat dari hasil analisis data, yaitu $r_{\text {hitung }}=0,45$ sedangkan $r_{\text {tabel }}=0,344$ dengan taraf signifikan $5 \%$ dan dengan jumlah sampel sebanyak 33. Dengan demikian $r_{\text {hitung }}$ dengan taraf signifikan 5\% menunjukan lebih besar dari pada nilai $r_{\text {tabel }}=0,344$ dan $r_{\text {hitung }}=0,45$; dimana $r_{\text {hitung }}>r_{\text {tabel }}$ atau $0,45>0,344$. Hasil tersebut dapat disimpulkan termasuk " Agak rendah ".Hal ini disebabkan banyak faktor yang mempengaruhi kesulitan belajar dan proses belajar. Faktor-faktor ekstrern yang lebih banyak berpengaruh terhadap koneksi matematika siswa, diantaranya lingkungan keluarga, lingkungan sekolah, dan lingkungan masyarakat.

\section{PENUTUP}

\section{Simpulan}

Berdasarkan dari hasil analisis data yang diperoleh $r_{\text {hitung }}$ dengan taraf signifikan 5\% menunjukan lebih besar dari pada nilai $r_{\text {tabel }}=0,344$ dan $r_{\text {hitung }}=0,45$; di mana $r_{\text {hitung }}>r_{\text {tabel }}$ atau $0,45>0,344$ maka dapat disimpulkan bahwa kesulitan belajar berpengaruh pada kemampuan koneksi matematika.

Kemampuan berfikir siswa dan kemampuan daya tangkap siswa bervariasi, jadi setiap siswa memiliki kemampuan tolak ukur pembelajaran yang berbeda dan tidak dapat disama ratakan.

Dengan demikian dapat disimpulkan bahwa ada hubungan kesulitan belajar matematika terhadap kemampuan koneksi matematika pada siswa kelas XI AK1 SMK Kartika 1 Surabaya.

\section{Saran}

Berdasarkan simpulan di atas, maka peneliti memberikan saran-saran sebagai berikut :

\section{Bagi Siswa}

a. Siswa diharapkan lebih aktif dalam proses pembelajaran berlangsung.

b. Siswa diharapkan lebih berani berkomunikasi menyampakan permasalahan dan hambatan yang 
Elok Hidhayati Hartanti : Hubungan Belajar Matematika Terhadap Kemampuan Koneksi Matematika Pada Siswa SMK Kartika 1 Surabaya

dihadapi dalam menyelesaikan permasalahan matematis.

2. Bagi guru

a. Sebaiknya diadakan penelitian yang lebih lanjut untuk mencari komponen-komponen lain yang mendukung, sehingga para guru

dapat membuat program latihan yang lebih baik untuk meningkatkan kemampuan koneksi matematis.

b. Untuk sekolah pinggiran bagi para guru sebaiknya menggunakan pembelajaran langsung, karena peserta didik di sekolah pinggiran kemampuan menerima pelajarannya beda dengan sekolah kawasan.

3. Bagi sekolah

a. Sekolah sebaiknya memberikan fasilitas yang memadahi untuk proses pembelajaran matematika.

b. Proses pembelajaran sebaiknya dilakukab dengan kondusif dan sebaiknya ekstrakulikuler dilakukan diluar jam efektif sekolah berlangsung agar siswa mendapatkan materi secara baik

\section{DAFTAR PUSTAKA}

A.M, Sardiman. 2005. Interaksi \& Motivasi Belajar Mengajar. Jakarta: PT. Raja Grafindo Persada.

Arikunto, Suharsimi. 2006. Prosedur Penelitian Suatu Pendekatan Praktik. Jakarta: Rineka Cipta.

Arikunto, Suharsimi. 2010. Prosedur Penelitian Suatu Pendekatan Praktik. Jakarta: Rineka Cipta.

Arikunto, Suharsimi. 2013. Prosedur Penelitian Suatu Pendekatan Praktik. Jakarta: Rineka Cipta.

Aunurrahman. 2009. Belajar Dan Pembelajaran. Bandung: Alfabeta.

Bobbi Deporter, Mark Reardon, and Sarah Singer-Nourie. 2010. Quantum Teaching. Bandung: Kaifa

Djamarah, Syaiful Bahri. 2011. Psikologi Belajar. Jakarta: Rineka Cipta.

Departemen Pendidikan dan Kebudayaan.1999. Kamus Besar Bahasa Indonesia. Jakarta: Balai Pustaka.

E. Slavin, Robert. 2011. Psikologi Pendidikan TeoriDan Praktik. Jakarta: Indeks. 